\title{
MIR376C Gene
}

National Cancer Institute

\section{Source}

National Cancer Institute. MIR376C Gene. NCI Thesaurus. Code C96010.

This gene is involved in the modulation of target gene expression. 